\title{
Emarketplace Performance Analysis Using PIECES Method
}

\author{
Munirul Ula $^{1 *}$, Rizal Tjut Adek ${ }^{2}$, Bustami Bustami² \\ ${ }^{1}$ Department of Information System, Universitas Malikussaleh, Aceh, Indonesia \\ ${ }^{2}$ Department of Informatics, Universitas Malikussaleh, Aceh, Indonesia \\ *Corresponding author E-mail: munirulula@ unimal.ac.id
}

Manuscript received 15 August 2021; revised 1 Sept 2021; accepted 15 Sept 2021. Date of publication 4 Nov 2021

\begin{abstract}
E-Marketplace is a place in cyberspace where prospective buyers meet each other to conduct transactions electronically through the internet medium. Like the market in the conventional sense, namely a meeting place for sellers and buyers, in the E-Marketplace, various companies in the world also interact without being limited by the territory of space (geography) and time. Therefore, an analysis of the performance of the website is needed to ensure the performance of the Bireuen emarketplace (meukat.com) website can run effectively in the future. The role of this emarketplace is very important, therefore in building emarketplace we must pay attention to several factors, namely: performance, information, economic, control, efficiency, and service, which is better known as the PIECES method. To analyze the performance of our self-developed emarketplace, was done by PIECES method. While the testing method in the performance analysis of the website uses the GTMetrix and Google Transparency applications. The results of the PIECES questionnaire on the dimensions of Information, Economy, Efficiency, and Service. The average score for the all dimensions is moderate, it is ranging from $42.8 \%$ to $51.45 \%$ and is in line with the expectations. The GTMetric test results of the Emarketplace website, shows that the average performance grade is $66 \%$ or grade D. This means that the quality of the Emarketplace website based on the index generated by Google is still low. It should be improved to provide good quality of service for users in future. The Emarketplace are also being analyzed by the Google transparency report, the result is "no unsafe content" was found, means this website is safe to visit. There are no applications that harm the users.
\end{abstract}

Keywords: Emarketplace Performance, PIECES Method, GTMetrix Test, Google Transparency Tool

\section{Introduction}

Website is one of the most widely used technology on the internet. Where the website provides a source of data and information that can be accessed by everyone via the internet. By using one of the browser software such as Internet Explorer, Mozilla Firefox, Opera Browser, or Google Chrome. By using this facility, the user can explore all the world's information and news [1]. Websites are made with various functions and various needs according to interests. The main purpose in making a website is to disseminate information, therefore a website must be able to convey the information contained in the website to site visitors [2].

E-Marketplace is defined as a place or arena in cyberspace where prospective buyers meet each other to conduct transactions electronically through the internet medium. Actually E-Marketplace is a form of e-commerce [3]. E-Marketplace is a separate market or trading arena (some management practitioners refer to it as Marketspace). Like the market in the conventional sense, namely a meeting place for sellers and buyers, in the E-Marketplace, various companies in the world also interact without being limited by the territory of space (geography) and time. Various products and services in various forms are tried to be offered by these "go internet" companies in various industrial domains, resulting in a value and trading volume that is no less large than the conventional market [4].

The role of the emarketplace is very important, therefore in building emarketplace you must pay attention to several factors, namely: performance, information, economic, control, efficiency, and service, which is better known as the PIECES method [5] where the PIECES method is an analytical method as a basis for obtaining the main issues more specific. The PIECES method has six assessment variables in evaluating, namely the first is performance is to assess whether the existing process or procedure is still possible to improve its performance and response time, which is the time required to complete a series of activities to produce certain outputs, the second is information[6]. Information is an assessment of whether 
existing procedures can still be improved so that the quality of the information produced is getting better. The third variable is economics, which is to assess whether the current procedure can still be increased in benefits (use value) or lower the cost of its implementation. The fourth variable is control. Control is to assess whether the current procedures can still be improved so that the quality of control is getting better, and its ability to detect errors or fraud is getting better as well. The fifth variable of the PIECES method is efficiency. Efficiency is to assess whether the current procedures can still be improved, so that an increase in operating efficiency is achieved, and the sixth variable or the last variable is Service which is to assess whether the current procedures can still be improved to achieve service quality improvements [6].

The testing method for analyzing the Emarketplace website is using the tools provided by GTMetrix (http://gtmetrix.com/). GTMetrix is a website to analyze web speed that is available for free using YSlow as an analyze engine and to display results and recommendations for what to do[7]. Yslow is an application created by engineers at Yahoo to measure website performance and provide suggestions for optimizing access speed. while Google transparency report is an application that can be used to determine the level of security of a website.

\section{Literature Review}

\subsection{Related Studies}

Previous research conducted by Firdaus Masyhur [8], the Performance of the Official Website of the Provincial Government in Indonesia concluded that the local government website is a means of communication to convey various information to the wider community. The existence of the website helps as well as cover the limitations of the government in terms of dissemination of various information so that the public does not experience information gaps. This survey research uses observation techniques in data collection. The object of observation is the website of the provincial government throughout Indonesia based on a list of local government websites obtained from the website of the Ministry of Home Affairs of the Republic of Indonesia. Website performance measurement is done using tools provided by GTMatrix. Based on the results of testing local government websites, it is found that the average Page Speed Grade is 59\% or in grade E. This means that the quality of local government websites based on the index generated by Google is still very low. The low quality of the web will certainly affect the performance of the website and will directly affect the interest of internet users to visit local government websites. The same thing was also produced by YSlow Grade from Yahoo where the average YSlow Grade was $74 \%$ or grade $\mathrm{C}$.

The PIECES method for website assessment has also been used by Adi Supriyatna [9] with the title "Analysis and Evaluation of User Satisfaction with Library Information Systems Using the PIECES Framework". From the research, it is concluded that based on the analytical method of the PIECES framework which consists of Performance, Information and data, economics, control and security, efficiency, and Service, the satisfaction level value of each domain is obtained, namely the PIECES domain gets a score of 3, 86 with the predicate satisfied, the information and data domain received a score of 3.68 with the predicate satisfied, the economics domain received a score of 4.38 with the predicate very satisfied, the control and security domain received a score of 3.65 with the predicate satisfied, the domain efficiency received a score of 4.2 with satisfied predicate and service domain obtained a score of 3.9 with satisfied predicate.

A study entitled "Analysis of the Implementation of the E-Puskesmas System Using the PIECES Method at the Pemancungan Padang Health Center in 2018. The purpose of this study is to analyze the implementation of the e-Puskesmas system using the PIECES (Perfomance, Information, Economic, Control, Efficiency \& Service) method. The results of the analysis found that the implementation of the e-Puskesmas was quite good, although in the implementation of the e-Puskesmas there were still some problems on the network such as speedy connections that were not optimal in addition to the security of access to e-Puskesmas that used a username and password account together as well as patient waiting time is too long because of network problems. The use of the e-Puskesmas application has been going well but there are still obstacles that interfere with the work of officers, it needs to be reported and followed up on a regular basis and it is better to evaluate the e-Puskesmas system in terms of the patient data input process so that it can increase effectiveness and efficiency in services [10].

The study entitled "Analysis of Measuring Service Quality on Consumer Satisfaction Using the PIECES Method" concludes that with the analysis of the pieces method, it provides an overview of the company in seeing the value of each employee in providing services based on performance indicators, information indicators, economic indicators, control indicators, efficiency indicators and indicators. services and with the application of the pieces analysis model, employees can see directly and can make improvements for each employee and make it easier for the company [11].

Likewise, the research entitled "Analysis of the KPU Website of Central Java Province with the Pieces Method" concluded that the KPU website so far has not been up-to-date and the color combination of the website display does not meet good human-computer interaction. The KPU is one of the state institutions that utilizes current information technology to disseminate information to the wider community in accordance with their fields and duties. The method used is the PIECES method which uses six evaluation variables, namely Performance, Information, Economic, Control/Security, Efficiency, and Service. This method is used to evaluate the KPU of Central Java Province. By analyzing the KPU website, it was found that the KPU's performance variables were lacking and the economic variables were lacking [6].

Other study, "System Implementation Analysis and Evaluation Smart Library Information AMIKOM Resource Center by the PIECES Framework Method" uses a quantitative descriptive approach, with data collection techniques using questionnaires and observation. Data analysis used the mean formula and used an interval scale. The results of the study stated that from the six domains of the Pices Framework method, it was said to be good with the average value of the mean namely performance (4.4), information (4.3), economical (3.9), control/scuritu (5.0), efficiency (4.55), service (4.43). Based on the research conducted, it can be concluded that the implementation of the smart library system in the AMIKOM 
resource center is stated to be good when viewed from the PIECES analysis and is quite effective and efficient in its use [12]. The results obtained from the journal are that the library information system based on the PIECES framework has been able to provide satisfaction to users. The PIECES method can be used to analyze the level of user satisfaction with the information system used.

Research by Moch Farid Fauzi [13], entitled Designing an Elementary School Student File Directory System, this research resulted in a Prototype System for designing a Student Directory System that can be used to facilitate the performance of homeroom teachers and administrative employees in the service process and management of student archive files. at the elementary school level.

Alfie Nur Rahmi study [14], entitled "PIECES Analysis of the Website-Based Online Tracer Study System at AMIKOM University Yogyakarta" concludes that in the information generated from online tracers not being relevant to the needs of DIKTI, BPC and alumni due to the contents of tracer questions that were never updated even though DIKTI has announced the latest form of tracer study in 2012.

\section{Methods}

\subsection{Type of Research}

The research method used is the evaluation research method. Evaluation research is an activity of collecting data or information, to be compared with criteria, then conclusions are drawn. This conclusion is referred to as the evaluation result. Therefore, the principle of evaluation research is to make decisions by comparing the data or information collected against the criteria, standards, or benchmarks used as comparisons for the data obtained [15].

\subsection{Research Instruments}

The instrument used in this research is by spreading. The questionnaire distributed in this study to evaluate and measure the Emarketplace website using the PIECES method, especially on the indicators of the PIECES framework, namely the Information, Economy, Efficiency, Service indicators by looking at the responses from respondent [16]. The weighting in the assessment is done using a Likert Scale. Likert scale is a variable to be measured translated into variable indicators [5][17]. Then the indicator is used as a starting point for compiling instrument items which can be in the form of statements or questions. The following is the weight of the assessment with a Likert scale [19]: The measurement for the Likert scale as follow; Strongly Disagree (1), Disagree (2), Neutral (3), Agree (4), and Strongly Agree (5). The Table 1 for the percentage value of each indicator is as follows:

Table 1. Table of Percentage Values

\begin{tabular}{ll}
\hline Answer & Description \\
\hline $0 \%-19.99 \%$ & Strongly (Disagree, Bad, or Very Less) \\
$20 \%-39.99 \%$ & Disagree or Disagree \\
$40 \%-59.99 \%$ & Fair or Neutral \\
$60 \%-79.99 \%$ & Agree or Like \\
$80 \%-100 \%$ & Very (Good, Agree, Like) \\
\hline
\end{tabular}

\subsection{Testing Techniques}

The technique in testing this website uses GTMetrix and Google Transparency Report. GTMetrix is a service that can be used to check the performance of a website. GTMetrix is actually a combination of the Yahoo Slow! and the web-based Google Pagespeed [7]. GTMetrix will measure the speed of the website and display the results in detail. The final points of GTMetrix are A to F. A means very good F means very bad/not optimal [8]. Meanwhile, Google Transparency Report is a service created by Google's security team to identify websites by informing users about whether the sites they are visiting are safe and providing details about detected threats and warnings that are displayed to users. By using this measuring tool, it can be known whether the Emarketplace website is safe for the public to visit.

\section{Results and Discussion}

This The results of this study were carried out by testing using the GT Matrix application on the dimensions of performance (Performance), while on the dimensions of Information, Economy, Efficiency, Service using responses from respondents to obtain points important about the Emarketplace website, while on the control dimension using the Google Transparency Report application.

\subsection{Questionnaire Results}

After processing the questionnaire data, the next step is to do the calculations. respondents' answers based on dimensions with each statement, namely:

\section{1) Dimension Information}

At the Information stage, analyze what information is provided by the Emarketplace website to the public. 
Table 2. Results Of Calculation of Information Dimensions

\begin{tabular}{llc}
\hline \multicolumn{1}{c}{ Information Analysis } & Likert Scale Percentage & Category \\
\hline The Emarketplace website always provides updated information. & $55.2 \%$ & Neutral \\
Information provided by the Website Emarketplace is always on time. & $53.4 \%$ & Neutral \\
Website provides information about updated Emarketplace activities & $52.1 \%$ & Neutral \\
The Emarketplace website provides news information & $47.5 \%$ & Neutral \\
$\begin{array}{l}\text { Information contained on the Emarketplace website already clear enough with } \\
\text { customer needs. }\end{array}$ & $48.3 \%$ & \\
\hline
\end{tabular}

From the calculation of the Table 2 on the Information dimension, the result is that the average respondent gives answers ranging from $47 \%$ to $55.2 \%$. In other words that on the Information dimension, the information provided by the Emarketplace website is sufficient to meet the expectations of respondents.

\section{2) Economic Dimension}

At this stage the analysis is related to the economic aspect, namely costs. Can using the website reduce costs in conveying information to the public? The Table 3 shows the results of the economic analysis questionnaire:

Table 3. Results Of Calculation of Economic Dimensions

\begin{tabular}{|c|c|c|}
\hline Economic Analysis & $\begin{array}{l}\text { Likert } \\
\text { Scale Percentage }\end{array}$ & Category \\
\hline ovides information about the trading system. & $43.6 \%$ & Neutral \\
\hline the Emarketplace website has been quite clear with & $38.6 \%$ & Do not agree \\
\hline in accordance with what Web visito & $46.2 \%$ & Neutral \\
\hline
\end{tabular}

The Emarketplace website is in accordance with what Web visitors want

Table 3 is the results of the Economic Dimension it is known that the average respondent gives answers between $38.6 \%$ to $46 \%$ which means that the Economic dimension on the Emarketplace website is sufficient and in accordance with the wishes of the respondents even though there are results of respondents who disagree with questions regarding the information contained on the Emarketplace website are clear enough user needs because the website itself has not been operating for a long time and is still in the completion stage.

\section{3) Dimension of Efficiency}

Efficiency analysis is the stage of analyzing how efficient the Emarketplace website is in conveying information to the public. The following are the details of the results of the efficiency analysis questionnaire:

Table 4. Calculation Of Efficiency Dimensions

\begin{tabular}{lll}
\hline Efficiency Analysis & Likert Scale & Category \\
\hline $\begin{array}{l}\text { The appearance of the Emarketplace website is easy to understand and easy to un- } \\
\text { derstand }\end{array}$ & $51.3 \%$ & Neutral \\
$\begin{array}{l}\text { The Emarketplace website menu is easy to remember, when clicking on the menu } \\
\text { will be shown quickly. }\end{array}$ & $53.4 \%$ & Neutral \\
The image displayed on the Emarketplace website opens quickly. & $55.6 \%$ & Neutral \\
The menu you are looking for on the website Emarketplace easy to find & $45.5 \%$ & Neutral \\
\hline
\end{tabular}

From the calculation of the Efficiency Analysis in table 4, the results are that the average respondent gives answers ranging from $51 \%$ to $52.25 \%$ in other words that the Efficiency Analysis in other words that the efficiency of the use of the Emarketplace website users has it is enough to understand the contents of each display of the Emarketplace website.

\section{4) Service Dimensions}

The services on the Emarketplace website that are needed are in accordance with the wishes of the community and what services are provided by the Emarketplace website. Here are also the results of the service analysis questionnaire:

Table 5. Calculation Results Of Service Dimensions

\section{Service Analysis}

The Emarketplace website has run as expected

Users or visitors are satisfied with the Emarketplace Website

The Emarketplace website provides good and appropriate information

The information provided on the Emarketplace Website is accurate

The Emarketplace website provides information on public services for the public
Likert Scale Category Percentage

$\begin{array}{ll}45.8 \% & \text { Neutral } \\ 42.7 \% & \text { Neutral } \\ 48.5 \% & \text { Neutral } \\ 51.1 \% & \text { Neutral } \\ 50.2 \% & \text { Neutral }\end{array}$




\subsection{Website Testing Results}

1) Performance

Web-based pagespeed GTMetrix measures the speed of the website and display the results in detail. The final points of GTMetrix are A to F. The advantage of GTMetrix is its stable analysis with a valid level of measurement consistency.

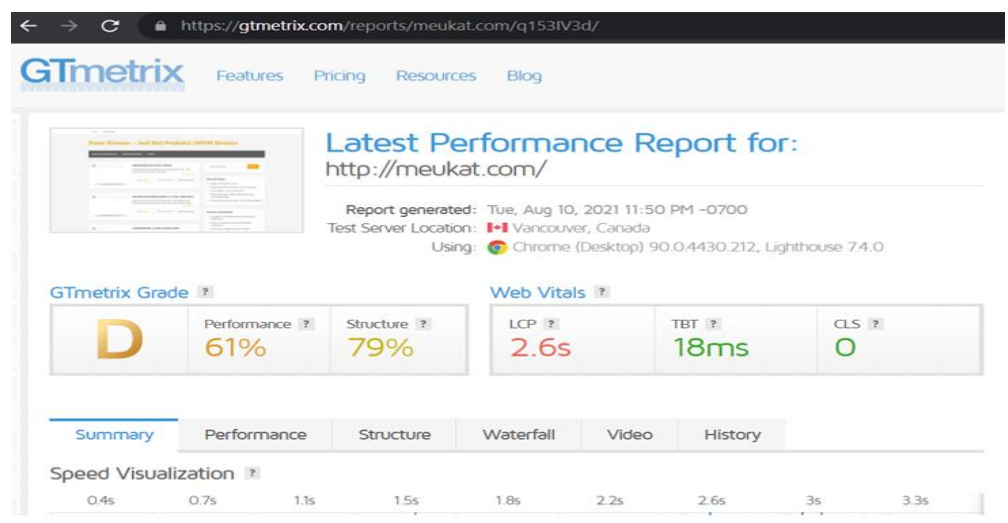

Fig 1. GT Metrix Measurement

Gtmetrix also provides a grade along with the score. The faster our website loads, the higher the grade and score. Grades are characterized qualitatively by the letters A, B, C, D, E, or F, while scores are characterized quantitatively by numbers. In addition, the results of the GTMetrix analysis are also accompanied by data on page load time, total page size, and total number of requests. The smaller the number means the speed of our blog is getting faster. A means very good $\mathrm{F}$ means very $\mathrm{bad} /$ not optimal.

Figure 1 is the result of GtMetrix measurements for the website meukat.com it appears that the pagespeed value is D (66\%) while the Yslow value is D (79\%). Other information that can be obtained is the download length of 2.6 seconds. Long download means less time the download, the website performance is getting better. Performance testing in this study using the GT Matrix application. GTMetrix is a service that can be used to check the performance of a website. GTMetrix is actually a combination of the Yahoo Slow! and Google. Web based page speed. GTMetrix will measure the speed of the website and display the results in detail. The final points of GTMetrix are A to F. A means very good F means very bad/not optimal.

\section{2) Control}

At this stage of control analysis will analyze in terms of the security of the website. Based on the analysis on the Emarketplace website content, the content is easy to read, understand and understand, because the content is in a language that is easily understood by the general public. The ease of interaction with the website is due to the menu structure that is easy to understand by users. Browser support (internet explorer, Mozilla, opera, chrome, and so on) is also good because the website can be run in several browsers. The font used on the page is easy to read because the font size is standard so that the writing can be easily read. The design and layout of the content that is easy to find because the design and layout of the content does not confuse the user, The menu structure is well structured so that the menu structure does not confuse users, The security of the website from malware or viruses is quite safe because this website does not contain viruses or active scripts that can interfere with computer activity.

At this stage the researcher also measures the security of the website by using the Google Transparency Report measuring tool. It is found that the Emarketplace website, after being analyzed by the transparency report, the result is no unsafe content was found, which means this website is safe to visit. There are no applications that harm the user.

\subsection{Discussion}

Based on the results of the calculations on the dimensions above, it can be concluded that the dimensions of information, economy, efficiency, and service using the PIECES method in the evaluation and measurement of the Bireuen Emarketplace website are good. can be seen from the table 6 as follows:

Table 6. Dimensional Results based on the PIECES method

\begin{tabular}{ll}
\hline Dimension & Average Score \\
\hline Information & $51.3 \%$ (Neutral) \\
Economy & $42.8 \%$ (Neutral) \\
Efficiency & $51.45 \%$ (Neutral) \\
Service & $47,66 \%$ (Neutral) \\
\hline
\end{tabular}

Based on the test results of the Emarketplace website, it was found that the average page speed grade was $66 \%$ or grade D. This means that the quality of the Emarketplace website based on the index generated by Google is still low, the same thing 
is also produced by YSlow Grade from Yahoo where the average YSlow Grade is 79\% or in grade D. The low quality of the web will certainly affect the performance of the website.

\section{Conclusion}

Based on the results of the analysis of the Bireuen Emarketplace website, the following conclusions are obtained:

1. This research work has elaborated the results of the PIECES questionnaire on the dimensions of Information, Economy, Efficiency, and Service. This result is based on the responses of 20 Bireuen Emarketplace users. The average score for the all dimensions is ranging from $42.8 \%$ to $51.45 \%$ and is in line with the expectations.

2. Based on the GTMetric test results of the Emarketplace website, it was found that the average performace grade was $66 \%$ or grade D. This means that the quality of the Emarketplace website based on the index generated by Google is still low.

3. The Emarketplace are also being analyzed by the Google transparency report, the result is "no unsafe content" was found, means this website is safe to visit. There are no applications that harm the users.

\section{References}

[1] S. M. Inayah, "Analisis Website Menggunakan Metode PIECES Studi Kasus DINHUBKOMINFO Kabupaten Banyumas," Sttt Telkom. 2017.

[2] H. O. L. Wijaya, "Implementasi Metode Pieces Pada Analisis Website Kantor Penanaman Modal Kota Lubuklinggau," JUSIM (Jurnal Sist. Inf. Musirawas), vol. 3, no. 1, pp. 46-55, 2018, doi: 10.32767/jusim.v3i1.289.

[3] E. Indrajit and Richardus, "E-commerce: Strategi Bisnis Di Dunia Maya. Jakar-ta: PT. Elex Media Komputindo, 2001.

[4] N. Huda, “Analisis Kinerja Website Bireuen Emarketplace Menggunakan Metode Pieces,” Sistemasi, vol. 8, no. 1, pp. 78-89,.

[5] A. R. Adiguna, M. Saputra Chandra, and F. Pradana, "Analisis dan Perancangan Sistem Informasi Manajemen Gudang pada PT Mitra Pinasthika Mulia Surabaya,” J. Pengemb. Teknol. Inf. dan Ilmu Komput., vol. 2, no. 2, pp. 612-621, 2018.

[6] M. K. Condro Laksono,Sasano Wibowo SE, Analisis Website Kpu Provinsi Jawa Tengah. Academ-ia.edu, 2014.

[7] H. Fryonanda and T. Ahmad, "Analisis Website Perguruan Tinggi Berdasarkan Keinginan Search Engine Menggunakan Automated Software Testing GTmetrix,” Anal. Website Perguru. Tinggi Berdasarkan, vol. 4, no. 2, pp. 179-183, 2017.

[8] F. Masyhur, "Kinerja Website Resmi Pemerintah Provinsi di Indonesia," Pekommas, vol. 17, no. 1. pp. 9-14, 2014, [Online]. Available: http://download.portalgaruda.org/article.php?article=266814\&val=6557\&title=Kinerja Website Resmi Pemerintah Provinsi di Indonesia.

[9] A. Supriyanta, Analisis dan Evaluasi Kepuasan Pengguna Sistem Informasi Perpustakaan Dengan Menggunakan Pieces Framework, vol. XI, no. 1. Karawang: Jurnal Pilar Nusa Mandiri, 2015.

[10] R. Muliansah and C. Budihartanti, "Analisa Pemanfaatan e-Puskesmas di Loket Pendaftaran pada Puskesmas Kecamatan Pademangan dengan Metode PIECES,” J. Comput. Sci. Eng., vol. 1, no. 1, pp. 17-29, 2020, doi: 10.36596/jcse.v1i1.22.

[11] Y. Asbar and M. A. Saptari, "Analisa Dalam Mengukur Kualitas Pelayanan Terhadap Kepuasan Konsumen Menggunakan Metode PIECES,” J. Visioner Strateg., vol. 6, no. 2, pp. 39-47, 2017.

[12] D. Dwiyantoro, "Analisis dan Evaluasi Penerapan Sistem Informasi Smart Library AMIKOM Resource Centre dengan Metode Pieces Framework," Tik Ilmeu J. Ilmu Perpust. dan Inf., vol. 3, no. 2, p. 109, 2019, doi: 10.29240/tik.v3i2.962.

[13] Moch Farid Fauzi and Sistem, Rancang Sistem Direktori Berkas Arsip Siswa Sekolah Dasar, vol. 91 , no. 4. Yogyakarta: Jurnal Ilmiah DASI, 2017.

[14] A. N. Rahmi, Analisis Pieces Sistem Tracer Study Online Berbasis Website Di Universitas AMIKOM Yogyakarta, vol. 18, no. 2. Yogyakarta: Jurnal Ilmiah DASI, 2017.

[15] N. F. Rozy, R. Ramadhiansya, P. A. Sunarya, and U. Rahardja, "Performance Comparison Routing Protocol AODV, DSDV, and AOMDV with Video Streaming in Manet," 2019, doi: 10.1109/CITSM47753.2019.8965386.

[16] H. N. Putra, "Analisis Pelaksanaan Sistem E-Puskesmas Dengan Menggunakan Metode PIECES Di Puskesmas Pemancungan Padang Tahun 2018," J. Rekam Medis dan Inf. Kesehat., vol. 1, no. 1, pp. 63-69, 2018.

[17] A. R. Dewi, “Analisis Sistem Informasi Pengolahan Data Nilai Mahasiswa Menggunakan PIECES pada Prodi Sistem Informasi," Query, vol. 5341, no. October, pp. 37-46, 2018. 